\title{
ГАРЯЧЕ ШТАМПУВАННЯ СТАЛЕВИХ ПОРОЖНИСТИХ ВИРОБІВ З ІНТЕНСИВНОЮ ПЛАСТИЧНОЮ ДЕФОРМАЦІЕЮ СТІНКИ І ДОННОЇ ЧАСТИНИ
}

Для виробництва порожнистих виробів середніх розмірів з тонкою стінкою змінної товщини використовують процеси гарячого зворотного видавлювання та подальшого холодного витягування 3 потоншенням через одну або дві послідовно розташовані матриці за декілька переходів 3 проміжними відпалами напівфабрикатів між переходами. Процеси гарячого видавлювання порожнистих напівфабрикатів із сталей достатньо добре вивчені в джерелі [1], в якому наведені рекомендації по проектуванню технології і штампового оснащення. Кількість переходів холодного витягування з потоншенням можна зменшити завдяки використанню гарячого витягування. В теперішній час виготовляється гідравлічне пресове обладнання, яке забезпечує високу швидкість деформування при гарячому формоутворенні. Це дозволяє реалізувати процеси штампування на такому пресі в наступній послідовності: спочатку виконується гаряче видавлювання порожнистого напівфабрикату, а потім гаряче витягування з потоншенням з нього виробу без проміжного підігріву, що суттєво підвищує продуктивність штампування порожнистих виробів. В наведеному джерелі практично відсутні дані по проектуванню приведеної технології, тому що виникають складнощі із забезпеченням температурного інтервалу штампування. Застосування методу скінченних елементів (МСЕ) для визначення параметрів гарячого штампування дозволяє суттєво зменшити час та витрати на підготовку виробництва різноманітних виробів [2, 3]. Особливо високу ефективність має використання МСЕ для встановлення параметрів гарячого штампування виробів з необхідним пропрацюванням структури металу пластичною деформацією по всьому об'єму або в окремих частинах виробів. Приклади виявлення потрібного пропрацювання на конкретних деталях, втому числі на порожнистих виробах із кольорових металів, приведені в роботах [4-8]. Таке пропрацювання приводить до отримання заданих згідно робочого креслення деталі механічних властивостей у здеформованому металі.

Метою роботи є встановлення за допомогою методу скінчених елементів параметрів гарячого штампування вісесиметричного порожнистого виробу із маловуглецевої сталі, яке включає зворотне видавлювання напівфабрикату та подальше витягування з потоншенням стінок і доштампуванням донної частини, із забезпеченням інтенсивного пропрацювання структури металу пластичною деформацією у стінці та донній частині для досягнення відповідних механічних властивостей.

Розрахунковий аналіз гарячого штампування проводили за допомогою моделювання з використанням скінченно-елементної програми DEFORM та циліндричної системи координат. Температура вихідної циліндричної заготовки із сталі AISI 1015 діаметром 100 мм і висотою 38 мм становила $1000{ }^{\circ} \mathrm{C}$. Для вказаної сталі рекомендують температурний інтервал штампування у межах $1100 \div 800^{\circ} \mathrm{C}$. Швидкість деформування (швидкість переміщення пуансонів) була $60 \mathrm{~mm} /$ сек. Тертя на контактуючих поверхнях враховували по Зібелю 3 коефіцієнтом тертя $\mu=0,2$. Попередній розігрів деформуючого інструменту складав $200{ }^{\circ} \mathrm{C}$.

Результати роботи. Розрахункові положення деформуючого інструменту в розрізі для процесу зворотного видавлювання напівфабрикату в розрізі показані на рис.1. Положення інструменту на початку видавлювання зображене на рис. 1, а. Заготовка 1 розміщена на опорі 2 у матриці 3. Деформування заготовки здійснюється пуансоном 4. При опусканні пуансона 4 отримується напівфабрикат 5. Напівфабрикат має виступ на донній частині зі сторони порожнини та на нижньому торці цісї частини. 
На рис. 2 приведена залежність зусилля видавлювання від переміщення пуансона. Зусилля постійно зростає та досягає максимального значення в кінці видавлювання. Виступ зі сторони порожнини формується при зусиллі 3,18 МН, виступ на торці донної частини - при зусиллі $3,74 \mathrm{MH}$, а формоутворення стінки закінчується при зусиллі $6 \mathrm{MH}$. При цьому отримується конусна частина на донній частині під кутом $20^{\circ}$ від вісі для подальшого витягування з потоншенням та циліндрична зовнішня поверхня стінки діаметром 118 мм.

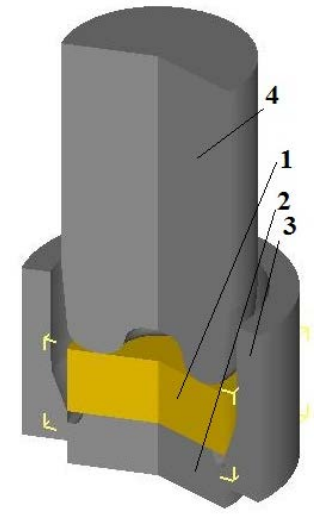

a

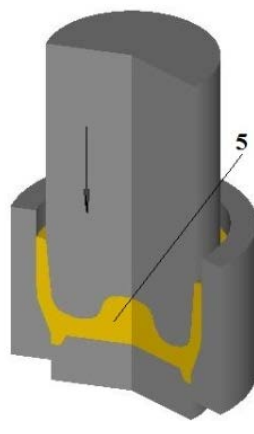

6

Рис. 1. Розрахункові положення деформуючого інструменту: а - на початку штампування, б - в кінці штампування

На рис. 3 зображені розподіл температури $\left(\mathrm{T},{ }^{\circ} \mathrm{C}\right)$ та інтенсивності деформацій $\left(\varepsilon_{\mathrm{i}}\right)$ у напівфабрикаті в кінці видавлювання. Тут і в подальшому наведена половина здеформованої заготовки, тонкими лініями зображений деформуючий інструмент, а розміри по вісях приведені в міліметрах (мм). На рис. 3, а показаний розподіл температури. Практично по всьому об'ємі напівфабрикату температура складає $\mathrm{T}=1000^{\circ} \mathrm{C}$. У стінці, в області контакту з пуансоном та в області контакту з матрицею, температура зменшилася до $\mathrm{T}=970{ }^{\circ} \mathrm{C}$. Таку ж температуру має здеформований метал у виступі донної частини зі сторони порожнини. В області цього виступу, яка контактує з пуансоном, температура зменшилася до $\mathrm{T}=890{ }^{\circ} \mathrm{C}$. До $\mathrm{T}=890{ }^{\circ} \mathrm{C}$ знизилася температура здеформованого металу в зоні напівфабрикату біля опори.

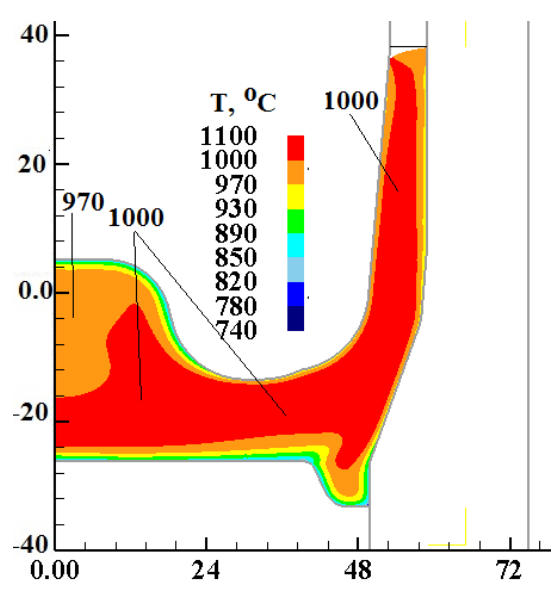

a

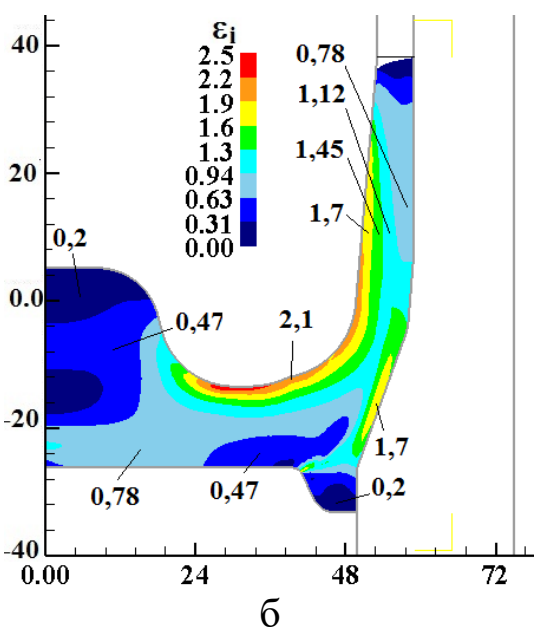

6

Рис. 3. Розподіли температури і інтенсивності деформацій у напівфабрикаті в кінці видавлювання: а - розподіл температури; б - розподіл інтенсивності деформацій

Пропрацювання структури металу пластичною деформацією після видавлювання

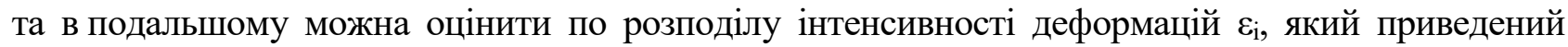
на рис. 3, б. У стінці по ширині отриманий нерівномірний розподіл. В шарах металу стінки 
зі сторони порожнини $\varepsilon_{\mathrm{i}}=1,7$. Далі по ширині стінки пропрацювання зменшується і досягає величини $\varepsilon_{\mathrm{i}}=0,78$ у зовнішніх шарах металу стінки. У виступі донної частини зі сторони порожнини отримані значення цих деформацій у межах $\varepsilon_{\mathrm{i}}=0,2 \div 0,47$. По висоті донної частини напівфабрикату інтенсивність деформацій зменшується від $\varepsilon_{\mathrm{i}}=2,1$ в зоні біля виступу пуансона до $\varepsilon_{\mathrm{i}}=0,78$ в області над опорою. У виступі на торці донної частини отримані значення у межах $\varepsilon_{\mathrm{i}}=0,2 \div 0,47$. Можна зробити висновок, що донна частина достатньо пропрацьовується пластичною деформацією при видавлюванні для досягнення потрібних механічних властивостей.

Для проектування деформуючого інструменту і штампу для видавлювання необхідно мати розподіли питомих зусиль на контактуючих поверхнях при максимальній величині зусилля видавлювання. Питомі зусилля на пуансоні та опорі можна оцінити по розподілу осьових напружень $\sigma_{\mathrm{z}}$, а на матриці - по розподілу радіальних напружень $\sigma_{\mathrm{r}}$ (рис. 4). Розподіл осьових напружень $\sigma_{z}$ показаний на рис. 4 , а. На поверхні пуансона виникають стискаючі осьові напруження зі значеннями у межах $\sigma_{z}=-680 \div-820$ МПа. На поверхні опори ці напруження досягають величини у межах $\sigma_{\mathrm{z}}=-680 \div-980$ МПа. Розподіл радіальних напружень $\sigma_{\mathrm{r}}$ по об'єму напівфабрикату приведений на рис. 4, б. На поверхні заготовки, яка контактує з матрицею, ці напруження отримані у межах $\sigma_{\mathrm{r}}=-220 \div-610$ МПа. Можна зробити висновок, що для виконання видавлювання при наведених розпираючих питомих зусиллях матриця може бути без бандажів.
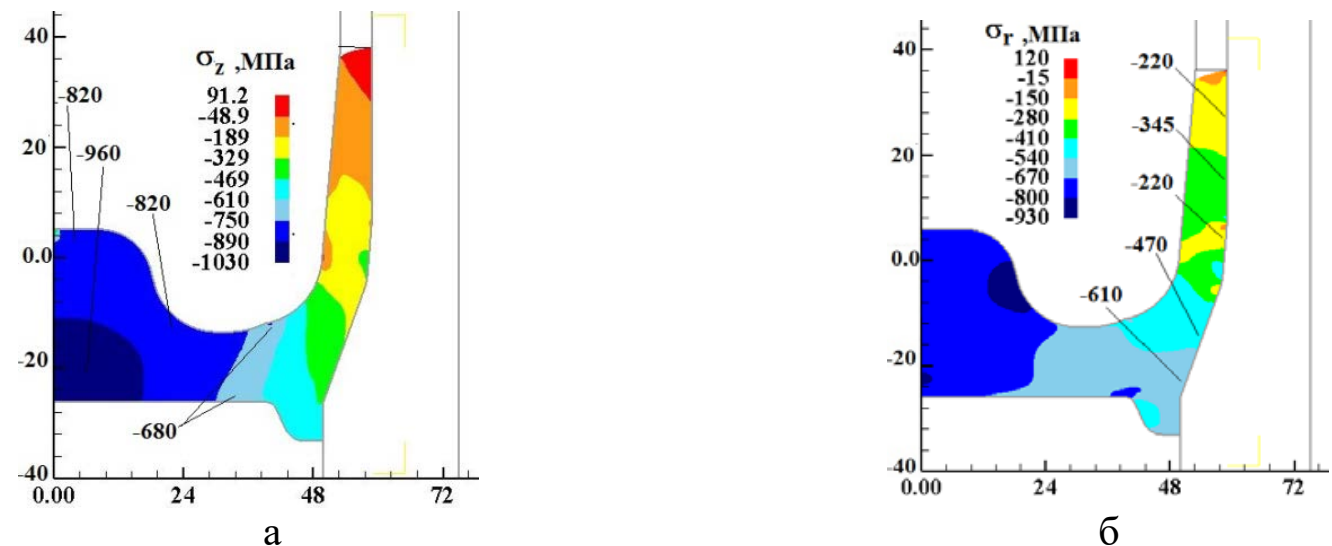

Рис. 4. Розподіли осьових $\sigma_{\mathrm{z}} \mathrm{i}$ радіальних $\sigma_{\mathrm{r}}$ напружень у напівфабрикаті після видавлювання: $\mathrm{a}-$ розподіл $\sigma_{\mathrm{z}}, \sigma-$ розподіл $\sigma_{\mathrm{r}}$

Далі приведені результати моделювання витягування з потоншенням. При розрахунку витягування враховані досягнуті деформації і температура у здеформованому металі, які отримані при видавлюванні з допущенням, що такі дані не змінюються при переносі напівфабрикату з позиції видавлювання на позицію витягування. Виявлено, що для отримання кінцевих розмірів виробу потрібне витягування через дві послідовно розташовані матриці із доштампуванням донної частини в кінці витягування через другу матрицю. При витягуванні використані вищенаведені швидкість деформування і підігрів деформуючого інструменту. На рис. 5 приведені в розрізі розрахункові положення деформуючого інструменту та здеформованого напівфабрикату з розподілом температури і інтенсивності деформацій після витягування у першій матриці. Після витягування у першій матриці зовнішній діаметр здеформованого напівфабрикату зменшується із 118 до 113 мм. На рис. 5, а показаний розподіл температури по об'єму здеформованого напівфабрикату після витягування у першій матриці (1 - перша матриця, 2 - друга матриця, 3 - пуансон). На цій стадії витягування ще зберігається температурний інтервал гарячого деформування. Тільки на внутрішніх шарах металу стінки температура зменшилася до величини $\mathrm{T}=820^{\circ} \mathrm{C}$. Розподіл інтенсивності деформацій

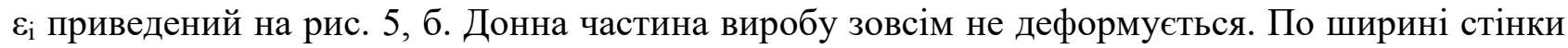
збільшується пропрацювання структури металу пластичною деформацією. У шарах металу стінки зі сторони порожнини величина таких деформацій вже складає $\varepsilon_{\mathrm{i}}=2,35$, а у зовнішніх шарах $-\varepsilon_{\mathrm{i}}=1,4$, що в середньому більше на величину 0,6 в порівнянні з отриманими даними після процесу видавлювання напівфабрикату (див. рис. 3, б). 


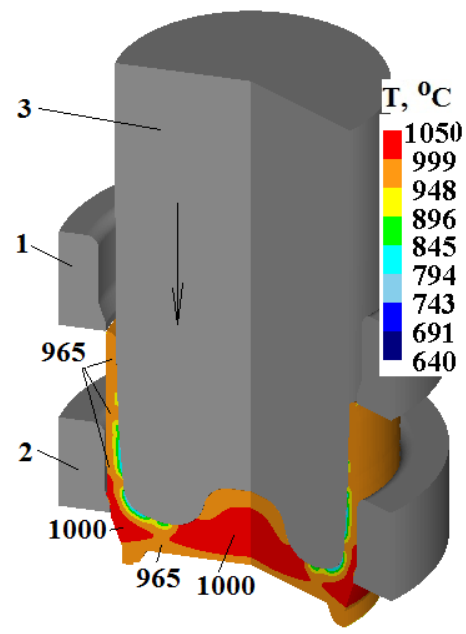

a

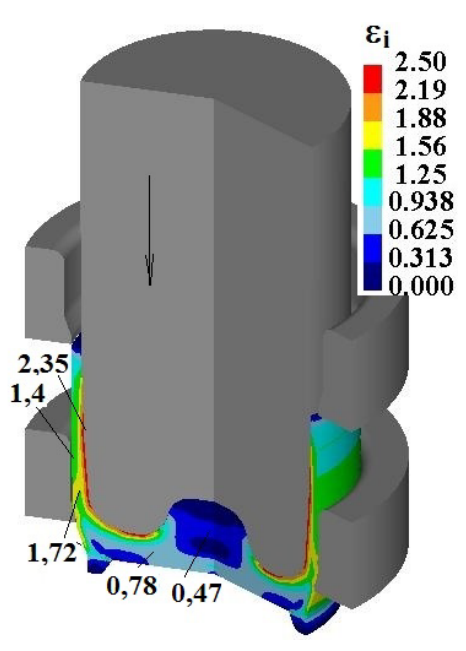

6

Рис. 5. Розподіли температури і інтенсивності деформацій у здеформованому напівфабрикаті після витягування у першій матриці:

a - розподіл температури; б - розподіл інтенсивності деформацій

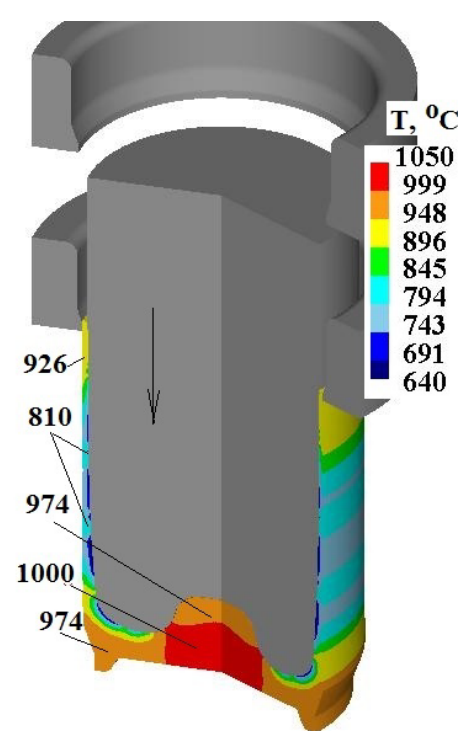

a

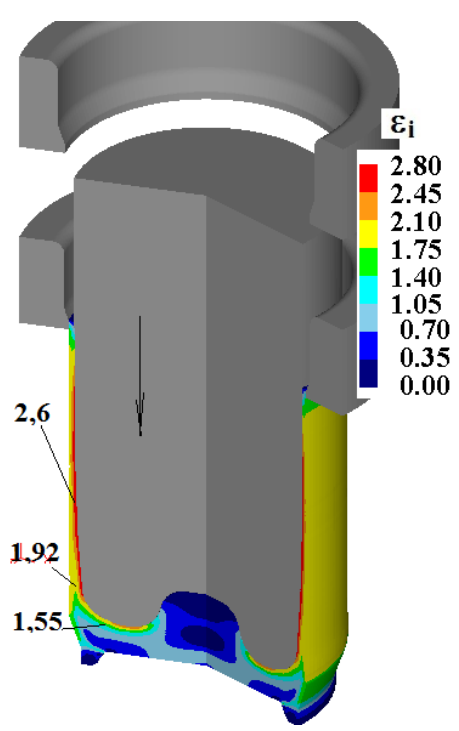

6

Рис. 6. Розподіли температури і інтенсивності деформацій у здеформованому напівфабрикаті після витягування у другій матриці:

a - розподіл температури; б - розподіл інтенсивності деформацій

Витягування у другій матриці починається після закінчення деформування у першій матриці. Після витягування у другій матриці зовнішній діаметр напівфабрикату зменшується із 113 до 110 мм, а донна частина також не деформується. На рис. 6 представлені в розрізі положення деформуючого інструменту і здеформованого напівфабрикату та розподіли по об'єму температури і інтенсивності деформацій в ньому після витягування у другій матриці. Розподіл температури показаний на рис. 6а. Температурний інтервал гарячого деформування стінки також зберігається. Температура у здеформованому металі стінки зменшилася до $\mathrm{T}=81{ }^{\circ} \mathrm{C}$. У донній частині здеформованого напівфабрикату температура зменшилася до $\mathrm{T}=975^{\circ} \mathrm{C}$. Це повністю достатньо для гарячого доштампування цієї частини після витягування. На рис. 6 , б представлений розподіл інтенсивності деформацій у здеформованому напівфабрикаті після витягування у другій матриці. Спостерігається подальше збільшення пропрацювання структури металу пластичною деформацією по ширині стінки. У шарах металу стінки зі сторони порожнини досягнута величина $\varepsilon_{\mathrm{i}}=2,6$, а у зовнішніх шарах $-\varepsilon_{\mathrm{i}}=1,92$. Необхідно відмітити, що має місце вирівнювання пропрацювання структури металу по ширині стінки. 
Доштампування донної частини відбувається у двох роз’ємних напівматрицях після завершення витягування у другій матриці. Сутність доштампування полягає у вивертанні виступу на нижньому торці донної частини з утворенням горизонтального фланця. Положення в розрізі деформуючого інструменту і отриманого виробу з розподілом в ньому інтенсивності деформацій в кінці доштампування приведене на рис. 7. Тут наведені: 1 і 2 - матриці для витягування 3 потоншенням, 3 - напівматриця, 4 - плита, 5 - пуансон. При доштампуванні стінка практично не деформується, а збільшується пропрацювання структури металу у отриманому фланці. Залежність зусилля витягування та доштампування від переміщення пуансона зображена на рис. 8. При витягуванні у першій матриці максимальне значення зусилля складає 230 кН. Витягування у другій матриці починається при суттєвому зменшенні зусилля деформування у першій матриці. При цьому максимальна величина зусилля досягає 210 кН. Процес доштампування також починається при суттєвому зменшенні цього зусилля та завершується при зусиллі 1600 кН. Таким чином, для виконання двох переходів штампування потрібний гідравлічний прес зусиллям не менше 8 МН. Кінцеві форма і розміри половини виробу приведені на рис. 9.

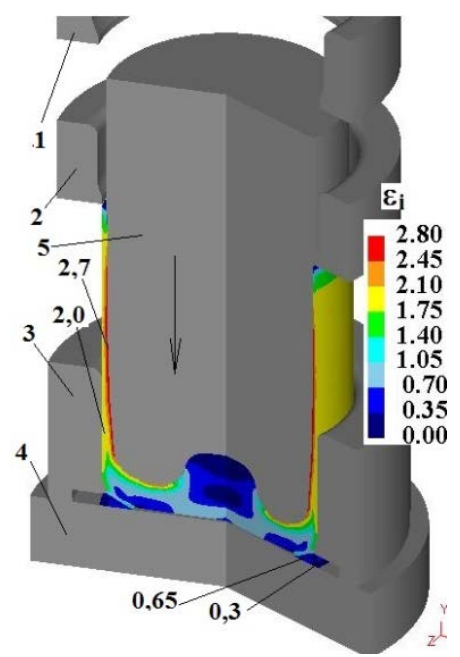

Рис. 7. Положення в розрізі деформуючого інструменту і виробу в кінці доштампування

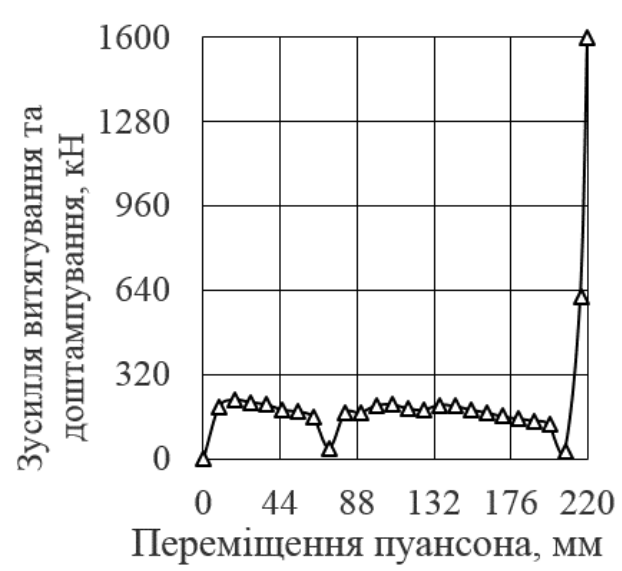

Рис. 8. Залежність зусилля витягування та доштампування від переміщення пуансона

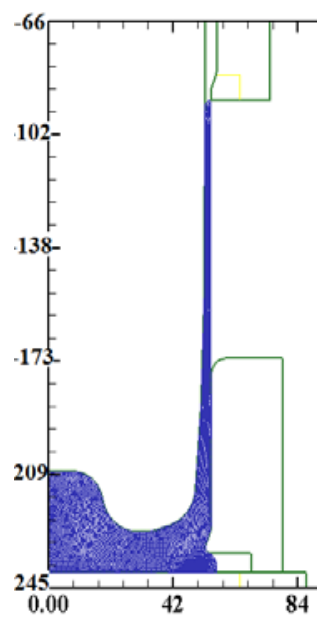

Рис. 9. Кінцеві форма i розміри виробу

\section{ВИСНОВКИ}

В статті приведений скінченно-елементний аналіз процесу гарячого штампування порожнистого виробу із маловуглецевої сталі з інтенсивним пропрацюванням пластичною деформацією стінки і донної частини, яке складається 3 двох переходів. На першому переході зворотним видавлюванням отриманий порожнистий напівфабрикат з виступами на донній частині з боку порожнини і на нижньому торці цієї частини. На другому переході витягуванням із потоншенням через дві послідовно розташовані матриці і доштампуванням донної частини забезпечені кінцеві форма і розміри виробу Визначені швидкість деформування і підігрівання деформуючого інструменту для забезпечення температурного інтервалу гарячого штампування упродовж виконання двох переходів. На кожному переходу встановлені зусилля, розподіл питомих зусиль на деформуючому інструменті. Пропрацювання структури металу пластичною деформацією оцінене за величиною інтенсивності деформацій. Встановлені ступені деформації для здійснення витягування із потоншенням. Приведені розподіли температури здеформованого металу після видавлювання та витягування. Показані розподіли інтенсивності деформацій у напівфабрикаті після видавлювання, в результаті виконання витягування, а також у виробі після доштампування донної частини. Відмічений більш рівномірний розподіл інтенсивності деформацій по ширині стінки в результаті витягування із потоншенням. Виявлені кінцеві форма і розміри виробу. 


\section{СПИСОК ВИКОРИСТАНОЇ ЛІТЕРАТУРИ}

1. Ковка и штамповка: Справочник в 4-х. т. Москва: Машиностроение. 1986. Т. 2. Горячая объемная штамповка. Под ред. Е. И. Семенова. 1986. 592 с.

2. Данченко В. Н., Миленин А. А, Кузьменко В. И. Компьютерное моделирование процессов обработки металлов давлением. Численные методы. Днепропетровск: Системные технологии, 2008. 448 с.

3. Снитко С. А., Калюжный В. Л. Конечно-элементное моделирование многопереходного формоизменения при производстве железнодорожных колес. Вестник НТУУ «КПИ». Машиностроение. Киев: НТУУ «КПИ», 2011. 11. С. 106-112.

4. Алиев И. С., Марков О. Е., Жбанков Я. Г. Влияние операции выворота поковки коническими плитами на распределение деформаций. Обработка материалов давлением. Краматорск: ДГМА, 2010. 3(24). С. 64-69.

5. Алиев И. С., Жбанков Я. Г., Таган Л. В. Управление напряженно-деформированным состоянием заготовки в процессах ковки крупных поковок. Обработка материалов давлением. Краматорск: ДГМА, 2013. 1(34). C. $50-59$.

6. Марков О. Е., Шарун А. О., Косилов М. С. Современные способы получения тонкостенных днищ ответственного назначения. Обработка материалов давлением. Краматорск: ДГМА, 2017. 1(44). С. 115-123.

7. Калюжний В. Л., Ярмоленко О. С. Зусилля деформування, напружено-деформований стан і температурний розподіл у здеформованій заготовці при гарячому зворотному видавлюванні порожнистих виробів із латуні. Вісник НТУ «ХПІ». Інновачійні технологї̈ та обладнання обробки матеріалів у машинобудування та металургії. Харків: НТУ «ХПІ», 2018. 23(1299). С. 28-33

8. Калюжный В. Л., Алиева Л. И., Алиев И. С., Горностай В. Н. Горячая объемная штамповка полых изделий из высокопрочного алюминиевого сплава с заданными механическими свойствами. Заготовительные производства в машиностроении. Москва, 2018. 16. 12. С. 18-25.

\section{REFERENCES}

1. Forging and stamping. Handbook. In 4 t., T. 2. Hot stamping. Ed. Semenov E.I. Moscow: Mechanical Engineering. 1987. 592 p. (in Russian).

2. Danchenko V.N., Milenin A.A, Kuzmenko V.Y. Computer design of processes of treatment of metals pressure. Numeral methods. Dnipropetrovsk: System technologies. 2008. 448 p. (in Russian)

3. Snytko S.A., Kaliuzhniy V.L. Finite element modeling of multi-junction shaping in the production of railway wheels. Bulletin of the NTUU "KPI". Mechanical Engineering. Kyev: NTUU «KPI». 2011. 11. pp. 106-112. (in Russian).

4. Aliiev I.S., Markov O.E., Zhbankov Ya.H. Influence of the operation of inverting the forging with conical and slabs on the distribution of deformations. Materials Working by Pressure. Kramatorsk: DSEA. 2010. 3 (24), pp. 64-69. (in Russian).

5. Aliiev I.S., Zhbankov Y.H., Tagan L.V. Control of the stress-strain state of the workpiece in the forging of large forgings. Materials Working by Pressure. Kramatorsk: DSEA. 2013. 1 (34), pp. 50-59. (in Russian).

6. Markov O.E., Sharun A.O., Kosylov M.S. Modern methods of obtaining thin-walled bottoms for critical purposes. Materials Working by Pressure. Kramatorsk: DSEA. 2017. 1 (44), pp. 115-123. (in Russian).

7. Kaliuzhniy V.L., Yarmolenko O.S. Deformation force, stress-strain state and temperature distribution in a deformed workpiece during hot reverse extrusion of hollow brass products. Bulletin of the NTU «KhPI». Innovative technologies and equipment in mechanical engineering and metallurgy. Kharkiv: NTU «KhPI». 2018. 23(1299). pp. 28-33. (in Russian).

8. Kaliuzhniy V.L., Aliieva L.I., Aliiev I.S., Hornostai V.N. Hot die forging of hollow products from highstrength aluminum alloy with specified mechanical properties. Blank production in mechanical engineering. Moscow. 2018. 16. 12, pp. 18-25. (in Russian).

Калюжний В. Л. - д-р техн. наук, проф. НТУУ «КПІ»;

Ярмоленко О. С. - аспирант НТУУ «КПІ»;

Малій Х. В. - - канд. техн. наук, ст. викл. ДДМА.

НТУУ «КПІ» - Національний технічний університет України «Київський політехнічний інститут імені Ігоря Сікорського».

ДДМА - Донбаська державна машинобудівна академія м. Краматорськ.

E-mail: kwl_2011@ukr.net 